\title{
THE EFFECT OF FINANCIAL LEVERAGE ON DEBT REPAYMENT CAPACITY : EVIDENCE FROM LISTED SHIPPING COMPANY IN INDONESIA
}

\author{
Danu Adi Setiawan \\ Khazar University, Azerbaijan
}

\begin{abstract}
Contrast with its potentiality in the largest Archipelago country on the world, shipping industry in Indonesia show unsatisfactory condition whereas its industry's national growth is below the overall industries growth and industry's nonperforming loan (NPL) rate is higher than national NPL. This condition is caused by the nature of shipping industry with a high level of business uncertainty and their liability's structure are dominated by banks and other financial institutions' longterm debts.

This research examines the relationship between financial leverage variable on the debt repayment capacity variable specifically to the banks and other financial institutions. The research population is shipping companies listed in Indonesia stock exchange with a number of samples is 12 companies. The consolidated financial statements in the period between 2014 and 2015 from the selected sample are used in this research.

Based on literature review, the variable of company's leverage is represented by a debt-equity ratio (DER). On the debt repayment capacity variable, the qualitative research method that is Delphi method is applied to define the ratio represented the variable. As the result, the debt repayment capacity variable is represented by Debt Security Coverage Ratio (DSCR).

The statistical method that is used in this research is correlation analysis. Correlation analysis is a group of techniques to measure the relationship between two variables that are financial leverage represented by DER and debt repayment capacity represented by DSCR.

The result shows that there is a negative correlation between financial leverage that is represented by DER and debt repayment capacity that is represented by DSCR. However, the correlation between them is considered weak with Pearson correlation coefficient less than 0,5 in absolute value or the influence of DER to the DSCR is insignificant
\end{abstract}

Keywords: Debt-Equity Ratio, Debt Repayment Capacity, Debt Security Coverage Ratio, Financial Leverage, Shipping Company 


\section{INTRODUCTION}

As the largest Archipelago country on the world with more than 18,000 islands, Indonesia has big potentiality in the marine industry. The need for transporting goods through sea both inside the country (domestic trade) and outside the country (international trade) is considered high. As a consequence, a shipping industry in Indonesia has vital function to support the country's economy.

Contrast with the potentiality of the shipping industry in Indonesia, the performance of overall shipping companies in Indonesia show the opposite condition. The growth of shipping industry in Indonesia is under the national growth. In quartal I 2016, the growth of Indonesia shipping industry was $2.7 \%$ year on year or below the national industry growth that reached $5.7 \%$ year on year (www.bankmandiri. co.id, 2016).

The similar condition is also seen from the data of Non-Performing Loan (NPL). A nonperforming loan (NPL) is the sum of borrowed money upon which the debtor has not made his scheduled payments for at least 90 days. A nonperforming loan is either in default or close to being in default. Once a loan is nonperforming, the odds that it will be repaid in full are considered to be substantially lower (www.investopedia. com, 2018). In semester I 2016, the gross NPL percentage in domestic shipping industry was $11.5 \%$ and international shipping industry was 9,09\% (www. bankmandiri.co.id, 2016). This number is much higher (more than 3 times) than national NPL that was $3 \%$ in the semester I 2016 (Otoritas Jasa Keuangan Indonesia, 2016).

Based on pre-research study especially through a deep interview with several businessmen in the shipping industry, the main reason of the highness of NPL rate in the shipping industry is because of the economic uncertainty. The shipping industry is a typical industry which has a high dependency on the economic condition. For example, when the commodity's price is high, the needs for transporting goods is also high and as the result, the price for shipping service increases significantly. However, in the last decade, the price of commodities is considerable fluctuative. For anticipating those fluctuations, many companies make a short-term agreement with shipping companies. As a consequence, most of the shipping companies in Indonesia don't have long-term contract to keep their business continuity.

On the other hand, as a nature of a company, the liability of shipping companies are dominated by banks or other financial institutions longterm debt (more than 5 years). Those loans are used for buying the ships as the main asset of shipping companies. Long-term company responsibility with an uncertainty of business continuity contributes to the increase of NPL rate of the shipping company in Indonesia.

Other than that, there is no strict regulation which controls about the minimum capital that shipping companies need to provide. The big amount of bank's loan without sufficient capital make the shipping industry become one of "fragile" industries, high return but very sensitive with economic changing.

Based on the industry nature that mentioned above, measuring the relationship between shipping companies' leverage and their ability to repay their responsibility to the bank has a high probability to show the clear result.

According to Myers (1984), leverage defines a capital structure of the firms. A capital structure consists of debt and 
equity financing. It is important for the management of the organizations to optimize the composition of debt and equity. Debt portion represents the other's claim and it reduces the risk of the owners (Eckbo, B.E.,1986). On the other hand, the highness of debt portion compared with company's equity will increase the credit risk. Credit risk can be defined as the risk that a borrower may not repay a loan and that the lender may lose the principal of the loan or the interest associated with it (www. investopedia.com, 2018).

It has been seen in different studies that financial leverage has an effect on corporate performance. This research will focus on the determining the effect of company's financial leverage to the corporate's performance to repay the loan (the probability of default).

\section{OBJECTIVE}

The main objective of this research is to investigate the effect of company's financial leverage on the capacity of company to repay their bank and other financial institution's loan.

After determining the most important variable/ratio of company's financial leverage and the company's debt repayment capacity, the specific objective of this research is to determine whether the Debt-Equity Ratio (DER) have any effect on Debt Security Coverage Ratio (DSCR) of quoted shipping companies in Indonesia.

\section{HYPOTHESIS DEVELOPMENT}

There is one previous study which examines the relationship between financial leverage and debt coverage ratio. Enekwe, Agu, and Nnagbogu (2014) determine the effect of financial leverage on interest coverage ratio (ICR) from listed Pharmaceutical Companies in Nigeria. The result shows that there are negative relationship between financial leverage and interest coverage ratio (ICR).

This previous research only defined the relationship between financial leverage and interest coverage ratio (ICR) where ICR is only one part of the debt repayment capacity factor. There is another important factor in debt repayment capacity which was not included in this research that is Current Portion Long Term Debt (CPLTD). However, it is clearly stated in the previous research that financial leverage has a negative relationship with one factor of debt coverage variable that is interest coverage ratio.

Based on the previous research, this research is conducted with an initial estimation that there is an influence of independent variables on dependent variables. The hypothesise that will be tested in this research are as follow:

Ho : There is no influence of company's financial leverage on company's debt repayment capacity to the bank and other financial institutions of quoted shipping companies in Indonesia.

H1a : There is an influence of company's financial leverage on company's debt repayment capacity to the bank and other financial institutions of quoted shipping companies in Indonesia in the positive direction.

$\mathrm{H} 1 \mathrm{~b}$ : There is an influence of company's financial leverage on company's debt repayment capacity to the bank and other financial institutions of quoted shipping companies in Indonesia in the inverse direction.

More than the hypothesise that mentioned above, the specific hypothesise related with a specific ratio in the variable tested that will be tested in this research as follow:

Ho : There is no influence of company's Debt-Equity Ratio (DER) on Debt Service Coverage Ratio (DSCR).

H1a : There is an influence of company's 
Debt-Equity Ratio (DER) on Debt Service Coverage Ratio (DSCR) in the positive direction.

$\mathrm{H} 1 \mathrm{~b}$ : There is an influence of company's Debt-Equity Ratio (DER) on Debt Service Coverage Ratio (DSCR) in the inverse direction.

\section{THEORY REVIEW}

\section{LEVARAGE AND DEBT TO EQUITY RATIO}

According to Qureshi et al, (2012) Leverage means funds from the creditors which are borrowed by the management of the organizations and it can be calculated by divided total liabilities to total equity. DER is a ratio for estimating the level of company's leverage. Debt-equity ratio can be defined as a proportion of debt to shareholders funds (net worth).

Acompany with high DER may provide higher returns to its shareholders, in line with the risk that is faced by the company compared to other companies with lower DER (Ross, Westerfield and Jordan, 2003). According to Bhandari (1988), a natural proxy for the risk of common equity of a firm is that firm's DER.

An increase in the DER of a firm increases the risk of its common equity, measuring risk in any reasonable way. Though it does not follow that, crosssectionally, the common equity of a higher DER firm always has higher risk and DER is expected to be positively correlated to the risk of common equity across firms.

\section{PREVIOUS RESEARCH}

There are several previous research which measure the effect of leverage variable on other company's financial variables such as profitability, stocks return, debt repayment capacity etc.

The main background and reason why this research is conducted in the previous study by Enekwe, Agu, and Nnagbogu (2014). This study examines the effect of financial leverage on financial performance from listed Pharmaceutical Companies in Nigeria. The result shows that the debt-equity ratio has a negative relationship with interest coverage ratio (ICR), has a negative relationship with return on Asset (ROA) and has a positive relationship with debt ratio (DR). In addition, the debt ratio (DR) has a negative relationship with Return on Asset (ROA) and has a negative relationship with interest coverage ratio (ICR).

Regardless its measurement for firm's profitability variables that is ROA, the previous study only examined the relationship between financial leverage and ICR which ICR is only one part of debt coverage rate. The total company's financial responsibility in term of repay the debts to the bank and other financial istitutions is interest and instalment for long term debt. In the accounting system, yearly instalment is represented by account of Current Portion of Long Term Debt (CPLTD). CPLTD can be defined as the section of a company's balance sheet that records the total amount of longterm debt that must be paid within the current year. For example, if a company owes $\$ 100,000$ and $\$ 20,000$ of it is due in the current year, it records $\$ 80,000$ as a long term debt and $\$ 20,00$ as CPLTD (www.investopedia.com, 2018).

As a result, this research will be conducted to complete the previous study. This research will examine the relationship between financial leverage variable and debt repayment capacity variable that includes two important components (interest and CPLTD).

Other than the research mentioned above, there are other several studies that examine the relationship between financial leverage variable and other financial variables. Most of them were determining the relationship between financial leverage variable and firm profitability variable such as Return 
on Equity (ROE), Return on Asset (ROA), income-increasing earnings management, cash flow per share etc.

Nadeem et al (2015) examine the effect of financial leverage on financial health from listed cement companies in Pakistan. The result shows that there is a positive and significant association between leverage and firm profitability.

Rastogi and Saxena (2016) examinethe effect of financial leverage on profitability from India companies. The result shows that debt ratio (DR) has a low degree of positive correlation with return on equity (ROE) whereas debt-equity ratio (DER) has a negative relationship with (ROE).

Akbarian (2013) examines the investigation effect of financial leverage and environment risk on performance firms of listed companies in Tehran stock exchange. The result shows that there is a negative relationship between financial leverage and cash flow per share and between variables market risk and economic risk with free cash flow per share positive significant. It also indicates that financial leverage, market risk and economic risk with a return of equity have a positive significant relationship.

Nasrollah et al (2013) study effect of financial leverage and investment diversification on income- increasing earning management. The results show that financial leverage coefficient is meaningful at a level of $95 \%$ of confidence, consequently, it can be concluded that financial leverage has an influence on income-increasing earnings management.

Enuju and Soocheong (2005) examine the effect of financial leverage on profitability and risk of Restaurant firms. They find that financial leverage does not influence the restaurant firms' profitability. It is noteworthy that the sign of financial leverage is positive meaning that more leveraged firms had more profits on average even though it was not statistically significant.

Barclay et al, (1995) assessed the relationship between leverage and profitability. The results have shown positive and significant correlation between the debt ratios and profitability. Return on assets and return on equity are positively associated with the profitability of the firms. On the other hand, Alkhati (2012) in his research found no statistical significant relationship between leverage and profitability of the firms.

\section{RESEARCH METHODOLOGY}

The methodology of research follows the step as explained below.

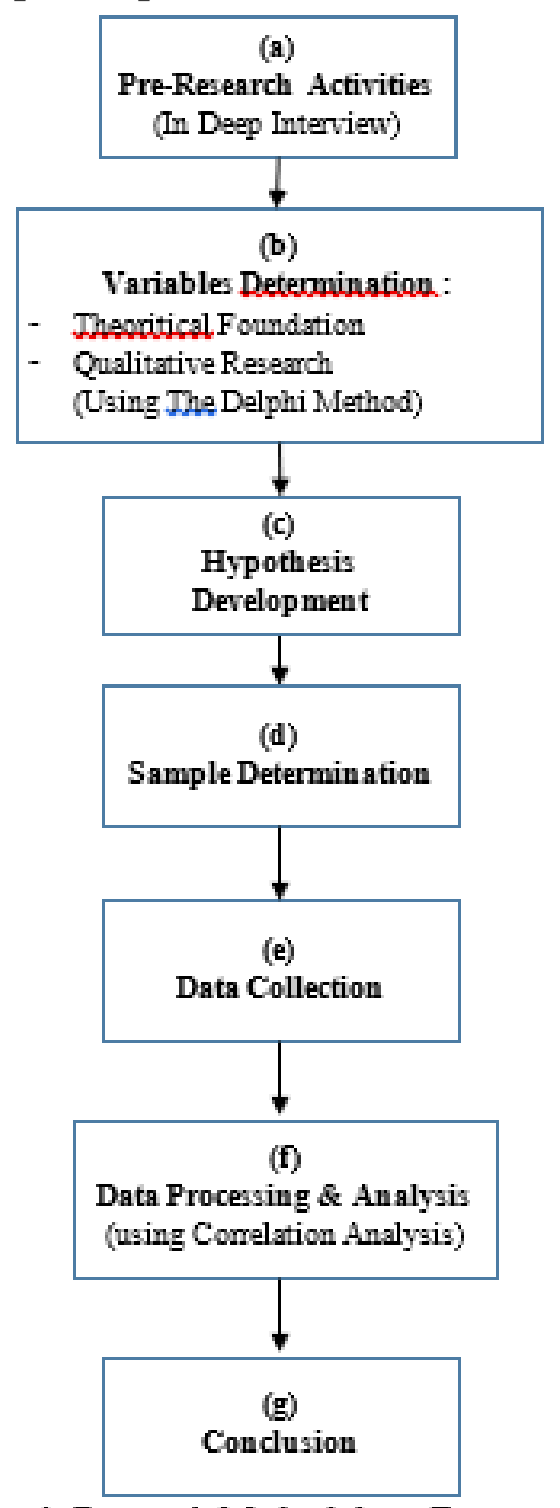

Figure 1. Research Methodology Framework 


\section{Explanation :}

a. Pre-research activity is a step to gather a lot of information about the nature of shipping industries including the issue of the financial leverage and variable which affect the company's debt repayment capacity. This step is done by deep interview to several businessmen in shipping industries. The main goal of this step is to develop the hypothesis and determining the variables option for the research.

b. A variable determination is a step to set up the variables that will be tested during the research. There two variables that are:

1) Independent Variable

According to Lind, Marchal and Wathen (2012, p498), independent variable can be defined as the variable used as the predictor. In this research, the variable which becomes the predictor is company's financial leverage. Regarding the theoretical study as mentioned at point $\mathrm{D}$, the ratio which represents the financial leverage variable is Debt-Equity Ratio (DER).

DER can be calculated based on formula :

$$
\text { DER = Total Debt / Total Equity }
$$

Total debts that are included in the calculation are bank's and other financial institutions' loan. The related parties' liability is excluded because the main objective of this research to measure the effect of company's financial leverage on company's debt repayment capacity to the bank and other financial institutions.

\section{2) Dependent Variable}

According to Lind, Marchal, and Wathen (2012, p498), the dependent variable is the variable being estimated. In this research, the variable which becomes the dependent variable is company's debt repayment capacity to the bank and other financial institutions.
There are several ratios which can be used to determine the variable of company's debt repayment capacity. Because there are many approaches related with repayment capacity determination and those approaches are based on each companies' policy and risk appetite, the ratio which most represented the variable of company's debt repayment capacity is determined by using qualitative research.

The technique that is used in this step is expert opinion technique specifically the Delphi Method. Delphi Method is a method that uses a panel of experts but they do not meet. The process is carried out by a sequential series of written questions and answers. The iterations are conducted until the range of answers is narrowed. Finally, a consensus (or convergence of opinions) is obtained (Keat, Young, and Erfle, 2014, p135).

Based on the technique, ten of experts/respondents are included in this step. Those experts are selected based on their exposure in the banking industry. All of the experts are credit analyst and underwriter which have more than 5 years experience and all of them have experience in analysing shipping companies. With those criteria, the experts are estimated to give the valid opinion related with the questions based on their knowledge, competencies and experiences in banking industry, credit sector and shipping companies analysis.

There are 3 sequential questions that were asked to the experts related to the most important ratio that represents the variable of company's debt repayment capacity. The steps are described in the following table below.

Table 1. Delphi Method Result

\begin{tabular}{ll}
\hline Number of Experts & \multicolumn{1}{c}{ Financial Ratios } \\
\hline $\begin{array}{l}\text { Sequent I (three variables that represent the company's } \\
\text { debt repayment capacity) }\end{array}$ \\
\hline
\end{tabular}




\begin{tabular}{ll}
\hline 2 (two) experts & $\begin{array}{l}\text { Debt Service Coverage Ratio } \\
\text { (DSCR), Debt to EBITDA, EBITDA } \\
\text { Growth }\end{array}$ \\
\hline 3 (three) experts & $\begin{array}{l}\text { Debt Service Coverage Ratio } \\
\text { (DSCR), Current Ratio (CR), EBIT- } \\
\text { DA Growth }\end{array}$ \\
\hline $\begin{array}{l}\text { Debt Service Coverage Ratio } \\
\text { (DSCR), Net Operating Cashflow } \\
\text { to Current Portion Long Term } \\
\text { Debt and Interest, Operating Profit } \\
\text { Margin }\end{array}$ \\
\hline $\begin{array}{l}\text { Debt Service Coverage Ratio } \\
\text { (DSCR), Current Ratio (CR), Debt } \\
\text { to EBITDA }\end{array}$ \\
\hline $\begin{array}{l}\text { Sequent II (two variables that represent the company's } \\
\text { debt repayment capacity) }\end{array}$ \\
\hline 7 (seven) experts & $\begin{array}{l}\text { Debt Service Coverage Ratio } \\
\text { (DSCR) \& EBITDA Growth }\end{array}$ \\
\hline 1 (one) expert & $\begin{array}{l}\text { Debt Service Coverage Ratio } \\
\text { (DSCR) \& Net Operating Cashflow } \\
\text { to Current Portion Long Term Debt } \\
\text { and Interest }\end{array}$ \\
\hline $\begin{array}{l}\text { Sequent III (one variable that represent the company's } \\
\text { debt repayment capacity) }\end{array}$ \\
\hline $\begin{array}{l}\text { Debt Service Coverage Ratio } \\
\text { (DSCR) \& Debt to EBITDA }\end{array}$ \\
\hline $\begin{array}{l}\text { (DSCR) } \\
\text { Interest }\end{array}$ \\
\hline
\end{tabular}

Based on the table above, the convergence of expert's opinion results Debt Service Coverage Ratio (DSCR) as the most important ratio that determines the company's debt repayment capacity variable.

DSCR can be calculated basen on formula :

DSCR $=$ EBITDA / [ Current Portion Long Term Debt (CPLTD) + Interest ]

To conclude, this research will measure the effect of Debt-Equity Ratio (DER) as an independent variable and represents the variable of company's financial leverage on Debt Service Coverage Ratio (DSCR) as dependent variable and represents the variable of company's debt repayment capacity.

c. After the previous two steps, the next step of the research is developing Hypothesis. This research is conducted with an initial estimation that there is an influence of independent variables on dependent variables. The hypothesis that will be tested in this research is explained on the point $\mathrm{C}$.

d. Before doing the core of the research (data collection, processing and analysis), the most important step is determining the research sample. The population is all of listed shipping companies in Indonesia stock exchange. The total population is 18 companies. However, during data collection, there are 6 companies which have no bank/other financial institution's loan and have negative gross profit. Those companies are excluded from the research's and as a result total sample in this research is 12 companies.

e. The research's data are collected by gathering and examining companies' financial statement consolidated that has been audited by the independent auditor. The consolidated financial statements that were used in this research are financial statements from the year 2014 until 2016. The reason of using financial statements data from 2014 is because there was significant macro economy changing in Indonesia and in the world during 2013 that could be seen from the drop of global oil price and the sharp decrease of Rupiah exchange rate in term of compared with US Dollar. With using data from before 2014, the condition of ceteris paribus could not be achieved in this research.

f. The method that is used in processing and analyzing data is a correlation analysis. Correlation analysis is a group of techniques to measure the relationship between two variables (Lind, Marchal, and Wathen, 2012, p463). 
The most important data in correlation analysis is correlation coefficient. According to Lind, Marchal and Wathen (2012, p466), a correlation coefficient is a measure of the strength of the linear relationship between two variables. The characteristic of a correlation coefficient is :

1) The sample correlation coefficient is identified by the lowercase letter $r$.

2) It shows the direction and strength of the linear relationship between two interval- or ratio-scale variables.

3) It ranges from -1 up to and including +1 .

4) A value near o indicates there is little relationship between the variables.

5) A value near +1 indicates a direct or positive relationship between the variables.

6) A value near -1 indicates inverse or negative relationship between the variable

g. The last step of the research process is determining the conclusion. The conclusion includes the main result interpretation, the weakness of the research and the suggestion for the related future research.

\section{RESULT \& DISCUSSION \\ 1. DESCRIPTIVE STATISTICS}

\begin{tabular}{cccr}
\multicolumn{5}{c}{ Table 2. Descriptive Statistics } \\
\hline Variables & Mean & $\begin{array}{c}\text { Standard } \\
\text { Deviation }\end{array}$ & $\begin{array}{c}\text { Sample Size } \\
(\mathrm{N})\end{array}$ \\
\hline DER & 1,26676 & 2,25493 & 35 \\
\hline DSCR & 1,07079 & 0,68441 & 35 \\
\hline
\end{tabular}

Descriptive statistics table above express that financial leverage as represented by Debt-Equity Ratio (DER) and debt repayment capacity as represented by Debt Security Coverage Ratio (DSCR) has positive mean value.

For Debt-Equity Ratio (DER), the mean value is 1,25735 with a high value of standard deviation that is 2,25816 . It means that the observation's data is widely dispersed from its mean value.

For Debt Security Coverage Ratio (DSCR), the mean value is 1,07079 with a low value of standard deviation that is 0,068441 . It indicates that the observation's data is low dispersed from its mean value.

\section{CORRELATION ANALYSIS}

Table 3. Correlation Analysis

\begin{tabular}{cc}
\hline Pearson Correlation & DSCR \\
\hline DER & $-0,34229$ \\
\hline
\end{tabular}

The correlation table above indicates that Debt-Equity Ratio (DER) has a negative correlation with Debt Security Coverage Ratio (DSCR) or indicates that as an increase of DER will affect the decrease of DSCR and vice versa. It means that the higher company's financial leverage represented by DER ratio, the debt repayment capacity that represented by DSCR will be lower and vice versa. As a result, to improve the capacity of debt repayment, the companies need to decrease the DER with decreasing the companies' debt or increasing the companies' equity or both of them.

Based on the data processing and analysis above, this research's result strengthens the previous result theory by Enekwe, Agu, and Nnagbogu (2014) which is shown that financial leverage variable has a negative relationship with debt coverage ratio variable (represented by interest coverage ratio). It is also concluded to accept Hypothesis $1 \mathrm{~b}$ (H1b) that there is an influence of company's financial leverage on company's debt repayment capacity to the bank and other financial institutions of quoted shipping companies in Indonesia in the inverse direction.

However, the Pearson correlation value between DER and DSCR is -0,34541 or in absolute value is under 0,5 . It indicates that the negative correlation between DER and DSCR is low or weak. 
The Table below shows the t-test for the correlation between DER and DSCR.

Table 4. T-Test Analysis

\begin{tabular}{cr}
\hline $\mathrm{t}-$ test & DSCR \\
\hline DER & 0,32744 \\
\hline
\end{tabular}

$\mathrm{T}$ value is less than 2 and this indicates that the correlation between DER and DSCR is not significant.

\section{CONCLUSION \& RECOMMENDA- TION}

Regarding on the research that has been conducted, it can be concluded that: 1. Based on the theoretical review, the variable of company's financial leverage can be represented by DebtEquity Ratio (DER) and based on qualitative research using The Delphi Method, the variable of debtrepayment capacity can be represented by Debt Security Coverage Ratio (DSCR).

2. There is a negative correlation between financial leverage that is represented by DER and debt repayment capacity that is represented by DSCR. However, the correlation between them is considered weak with Pearson correlation coefficient less than 0,5 in absolute value or the influence of DER to the DSCR is insignificant.

Against this backdrop, the researcher recommended among others:

1. Due to the high uncertainty of shipping company business continuity as a result of industry nature, it is important for the management to control their capital structure before they decide to take a new loan from banks or other financial institutions. Checking whether the equity is sufficient or not compared with the total loan will be vital action to maintain the company's ability to repay all of their financial responsibility to the banks or other financial institutions.

2. It is important for the regulator to make a policy related to the capital adequacy in the shipping industry. It will help to maintain the overall shipping companies' debt repayment capacity in order to contribute to the shipping industry performance.

\section{LIMITATION AND FUTURE RE- SEARCH}

There are several limitations in this research as the following points below.

1. The measurement of the relationship between two variables tested is based on secondary data (public consolidated financial statements) to that extent it has limitations.

2. Due to the lack of availability of certain data regarding confidentially of information, the study only gathers the evidence from listed shipping companies in Indonesia Stock Exchange.

Based on the research process and result, there are several points that can be suggested for the future research related with the topic of measuring the effect of financial leverage variable on the debt repayment capacity variable as the following points below :

1. The low correlation coefficient between financial leverage and debt repayment capacity variable that means insignificant relationship has possibility come from the research objects that focus only on listed companies which have relatively strong equity structure than unlisted companies. For the next research, expanding the research objects both form unlisted with relatively weaker equity structure without subsidiaries support and listed companies with stronger equity structure will contribute to the clearer research's result.

2. This type of research can be followed by other types of research such as defining the maximum Debt-Equity Ratio (DER) to maintain the debt 
repayment capacity or determining the amount of capital (the authorized, issued and outstanding stocks) that the company should provide in order to maintain the debt repayment capacity for shipping companies. It will be applicable in shipping industry especially for the regulator in determining the capital adequacy.

\section{REFERENCES}

Akbarian, S. 2013. The investigation Effect of Financial Leverage and Environment Risk on Performance Firms of Listed Companies in Tehran Stock Exchange, 8(3) : 249-255.

Alkhati, kh. 2012. The determinants of leverage of listed companies. International Journal of Business and Social Science, 3(24) : 78-83.

Barclay, M.J., Smith, C., and Watts, R. 1995. The determinants of corporate leverage and dividend policies. Journal of Applied Corporate Finance, $7:$ 4-19.

Bhandari, Laxmi Chand. 1988. Debt/ Equity Ratio and Expected Common Stock Return : Empirical Evidence. Journal of Finance, 63 (June).

Eckbo, B. E., 1986. Valuation Effects of Corporate Debt Offerings. Journal of Financial Economics, 15 : 119151.

Enekwe, Chinedu Innocent., Agu, Charles Ikechukwu., and Nnagbogu, Eziedo Kenneth. 2014. The Effect of Financial Leverage on Financial Performance : Evidence of Quoted Pharmaceutical Companies in Nigeria. IOSR Journal of Economics and Finance, 5(3) : 17-25.

Enuju, Y and Soocheong, J. 2005. The effect of Financial Leverage on Profitability and Risk of Restaurant Firms Journal of Hospitality Financial Management, 13(1) : $1-18$.
Keat, Paul G., Young, Philip K. Y., and Erfle, Stephen E. 2014. Managerial Economics : Economic Tools for Today's Decision Makers, 7th Ed. New Jersey : Pearson Education.

Lind, Douglas A., Marchal, William G., and Wathen, Samuel A. 2012. Statistical Techniques in Business and Economics. 15th Ed. New York : The Mc Graw-Hill/Irwin.

Myers, S. C. 1984. The Capital Structure Puzzle. Journal of Finance, 39(3) : 575-592.

Nadeem, M., Ahmad, R., Ahmed, A., Ahmad, N., Batool, S.R., KhalilUr-Rehman. 2015. The Effect of Leverage on Financial Health of The Firms : A Study from Cement Industry of Pakistan. Industrial Engineering Letters, 5(5).

Nasrollah, T., Mohammad, A.O., and Seyed, H.S.E. 2013. Effect of Financial Leverage and Investment Diversification on Income - Increasing Earnings Management. Middle-East Journal of Scientific Research, 16(6) : 836-844.

Qureshi, M.A., Imdadullah, M., \& Ahsan, T. 2012. What determines leverage in Pakistan? A panel data analysis. African Journal of Business Management, 6(3) : 978-985.

Rastogi, Sanjay., and Saxena, Pradeep. 2016. Leverage and Firm's Value : An Empirical Review of Concept with Reference to High Leveraged Indian Companies. International Journal of Research in IT and Management, 6(10) : 99-104.

Ross, A. Stephen., Westerfield, Randolph W., and Jordan, Bradford D. 2003. Fundamentals of Corporate Finance. 6th Ed. New York : Mc Graw-Hill. 